\title{
First Volcanic Plume Measurements by an Elastic/Raman Lidar Close to the Etna Summit Craters
}

\author{
Antonella Boselli', Simona Scollo2*, Giuseppe Leto ${ }^{3}$, Ricardo Zanmar Sanchez ${ }^{3}$, \\ Alessia Sannino ${ }^{4}$, Xuan Wang ${ }^{5}$, Mauro Coltelli ${ }^{2}$ and Nicola Spinelli ${ }^{4}$ \\ ${ }^{1}$ Consiglio Nazionale delle Ricerche, Istituto di Metodologie per I'Analisi Ambientale, CNR-IMAA, Tito Scalo, Italy, ${ }^{2}$ Istituto \\ Nazionale di Geofisica e Vulcanologia, Osservatorio Etneo, Catania, Italy, ${ }^{3}$ Istituto Nazionale di Astrofisica - Osservatorio \\ Astrofisico di Catania, Rome, Italy, ${ }^{4}$ Dipartimento di Fisica - Università di Napoli "Federico II", Consorzio Nazionale \\ Interuniversitario per le Scienze Fisiche della Materia (CNSIM), Naples, Italy, ${ }^{5}$ Dipartimento di Fisica, Consiglio Nazionale \\ delle Ricerche, Istituto Superconduttori, Materiali Innovativi e Dispositivi, CNR-SPIN, Università di Napoli "Federico II", \\ Naples, Italy
}

\section{OPEN ACCESS}

Edited by:

Clive Oppenheimer, University of Cambridge, United Kingdom

Reviewed by: Corrado Cimarelli,

Ludwig-Maximilians-Universität

München, Germany

Matthias Tesche,

University of Hertfordshire, United Kingdom

${ }^{*}$ Correspondence:

Simona Scollo

simona.scollo@ingv.it; simona.scollo@ct.ingv.it

Specialty section:

This article was submitted to Volcanology,

a section of the journal

Frontiers in Earth Science

Received: 28 February 2018

Accepted: 10 August 2018 Published: 24 September 2018

Citation:

Boselli A, Scollo $S$, Leto $G$, Sanchez RZ, Sannino A, Wang $X$, Coltelli $M$ and Spinelli N (2018) First Volcanic Plume Measurements by an Elastic/Raman Lidar Close to the Etna

Summit Craters.

Front. Earth Sci. 6:125. doi: 10.3389/feart.2018.00125
Volcanic emissions represent a well-known hazard mainly for aviation safety that can be reduced with real time observations and characterization of eruptive activity. In order to mitigate risks from volcanic ash, Lidar observations allow to perform immediate and accurate detection of volcanic plumes, quantify volcanic ash concentration in atmosphere and characterize optical properties of volcanic particles, improving modeling of volcanic ash clouds and their potential impact. From 14 to 17 December, 2013, Mt. Etna, in Italy, showed an intense Strombolian activity from the New South East Crater (NSEC). Lidar measurements were performed in Catania, pointing at a thin volcanic plume, clearly visible and dispersed from the summit craters toward the South East. Real-time Lidar observations captured the complex dynamics of the volcanic plume along with the pulsatory nature of the explosive activity and allowed to analyze the geometrical, optical and microphysical properties of the volcanic ash. Both the aerosol backscattering $\left(\beta_{A}\right)$ and the extinction coefficient $\left(\alpha_{A}\right)$ profiles at $355 \mathrm{~nm}$, and their ratio [the Lidar Ratio $(L R)]$ were measured near the volcanic source using an Elastic/Raman Lidar system. Moreover, calibrated particle linear depolarization values $\left(\delta_{A}\right)$ were obtained from Lidar profiles measured in the parallel and cross polarized channels at $355 \mathrm{~nm}$, thus allowing to characterize the particle shape. The $\beta_{A}$, LR, and $\delta_{A}$ values were used to estimate the ash concentration $(\gamma)$ profiles in the volcanic plume. This is the first study of optical properties of volcanic particles through Elastic/Raman measurements near volcanic summit craters and one of few studies which quantify the impact of weak eruptive activity in atmosphere, demonstrating that ash concentration from this type of activity was lower than the safety concentration threshold established by the International Civil Aviation Organization.

Keywords: Etna, volcanic aerosol, Elastic/Raman Lidar, optical properties, ash concentration

\section{INTRODUCTION}

The amount and composition of silicate particles and gasses emitted during volcanic eruptions are the result of very complex processes (Robock and Oppenheimer, 2003) which depend on different variables, such as chemistry of magma and mechanisms of its ejection and removals. During explosive eruptions, silicate particles and gasses mainly made of water vapor, carbon, and 
sulfur dioxides, are continuously released in the atmosphere (Sparks et al., 1997). Volcanic aerosols interact with the Earth's dynamic atmosphere affecting both terrestrial and marine ecosystems, human health, and microphysical processes in clouds and climate (Delmelle et al., 2002; Delmelle, 2003; Horwell, 2007; Ayris and Delmelle, 2012; Witt et al., 2017). Eruption produced aerosol strongly influence air quality especially in regions close to active volcanoes, nonetheless these effects may also be found many kilometers away from the volcanic vent at a regional scale (e.g., Azzopardi et al., 2013; Ayris et al., 2014). Volcanic emissions also represent a serious hazard to aviation safety because of the well-known damages to airplane engines and the drop of atmospheric visibility (Miller and Casadevall, 2000; Guffanti et al., 2005; Weinzierl et al., 2012; Kueppers et al., 2014; Song et al., 2014).

The volcanic plume impact reduction, which is nowadays a mandatory and scientifically recognized need (Bonadonna et al., 2012), can be better understood only with real-time observations. Real-time observations provide a unique opportunity to follow the volcanic process evolution, characterizing the eruption intensity variation over time (Bonadonna et al., 2015; Scollo et al., 2015). Furthermore, the knowledge of the atmospheric particles content may be very useful to define the eruption style and discriminate sulfate and/or water vapor dominated plumes that is very important to understand their atmospheric contribution, having the erupted particles many implications in climate and environmental effects (Scollo et al., 2012a,b). In this respect, remote sensing instruments can improve the monitoring capability of volcanic ash dispersion and fallout, helping the data interpretation and optimization for a realtime alert and rapid warning dissemination (Ripepe et al., 2013; Corradini et al., 2016). Results of real time observations are also useful to improve volcanic ash forecasts (Scollo et al., 2015).

Among the remote sensing techniques, Lidar represents one of the most efficient techniques in the atmospheric studies, since it gives reliable information on the characteristics of particles and gas with high spatial and temporal resolution. During the 2010 Eyjafjallajökull volcano eruption (Bonadonna et al., 2011; Gudmundsson et al., 2012; Stevenson et al., 2012), Lidar systems demonstrated their potentiality to study the volcanic emissions impact on a continental scale giving quantitative data about the presence of the volcanic cloud and its layering and optical characteristics (Ansmann et al., 2010, 2011; Marenco and Hogan, 2011; Marenco et al., 2011; Papayannis et al., 2012; Sicard et al., 2012; Navas-Guzmán et al., 2013; Pappalardo et al., 2013; Trickl et al., 2013; Balis et al., 2016). During the Eyjafjallajökull eruption, near real time data were available from ground based Lidar of the European Aerosol Research Lidar NETwork (EARLINET), giving large scale information on both particle content and ash concentration.

Mount Etna in Italy is one of the most active volcanoes of the world and, for this reason it is regularly monitored mainly by several ground-based instruments (e.g., Scollo et al., 2014). Recently, the Lidar technique has been routinely used to monitor Etna's explosive activity successfully giving unique information on the aerosol properties above the volcano (Scollo et al., 2012a; Mereu et al., 2018). Most of the papers concerning Lidar monitoring of volcanic plume analyzed the properties of aged volcanic particles transported over long distances in the troposphere and stratosphere (Sassen et al., 2007; Wang et al., 2008; Miffre et al., 2011; Kokkalis et al., 2013) while Lidar measurements of fresh volcanic ash in the proximity of active craters are still limited. The main limitation in using Lidar techniques is the decrease of the signal dynamic due to the presence of high optical depth layers. However, this constraint is mainly related to large explosive eruptions, which are not so frequent at Etna. Nonetheless, low concentration plumes produced by small intensity explosive eruptions could contaminate the air space over the near international airport in Catania, located only $26 \mathrm{~km}$ away from Etna summit's craters. Low intensity activity is not considered dangerous for aviation safety because the amount of associated ash would be considered not harmful for aircrafts. However, so far no measurement ever proved that the ash concentration associated to this type of activity is lower than the safety concentration threshold established by the International Civil Aviation Organization (ICAO, 2010).

The elastic backscatter Lidars are the most common and low cost systems able to measure geometrical features of an aerosol layer in the atmosphere and the aerosol backscatter coefficient. Lidars with Raman capabilities give a better characterization of the aerosol properties by simultaneously measuring the aerosol backscattering and extinction profiles. This allows to directly determining the extinction-to-backscatter ratio profile, also called LR. The LR parameter depends on the shape, size, and chemical composition of the aerosol (Ackermann, 1998; Müller et al., 2007), and it is useful to characterize the aerosol typology. Theoretical and experimental values of these parameters are reported in the literature for different aerosol types but studies of LR of freshly ejected volcanic ash are still few. Raman measurements carried out during the 2010 Eyjafjallajokull eruption showed, for example, LR values ranging between 50 and 82 steradians (sr) (Ansmann et al., 2010; Marenco and Hogan, 2011; Hervo et al., 2012; Mona et al., 2012). LR reported values, measured over Europe many kilometers away from the volcano, can change with time and distance from it and are indicative of a modification of the volcanic plume composition during the transport in the troposphere. Nevertheless, to the best of our knowledge, measurements of LR of volcanic ash performed shortly after its emission are not yet available at Etna.

A direct measurement of LR has been reported here as proxy from Etna at about $25 \mathrm{~km}$ away from the summit craters. The LR data measurements on freshly ejected volcanic aerosol offer great potential for sensitivity studies in transport and climatological model applications, hence, represent a reference value for Lidar applications to volcanic emissions. In this paper, we present the results of Elastic/Raman Lidar measurements carried out during the 16 December, 2013 Etna explosive activity and we show the measurements of volcanic plume optical parameters detected near the summit craters. 


\section{MATERIALS AND METHODS}

\section{Volcanological Data}

The Istituto Nazionale di Geofisica e Vulcanologia, Osservatorio Etneo (INGV-OE) performs daily forecast of volcanic ash for some eruptive Etna scenarios using automatic procedures that download weather forecast data from meteorological mesoscale models, run models of tephra dispersal, plot hazard maps of volcanic ash dispersal and deposition for certain scenarios and publish the results on the Italian Civil Protection dedicated web-site (Scollo et al., 2009). The system has been working since 2009 and, furthermore, since 2012 forecasts include also the Maltese area, in the frame of the VAMOS SEGURO (Volcanic Ash Monitoring and ForecaSting between Sicilia and Malta arEa and sharingG of the resUlts foR aviatiOn safety) project $^{1}$. Moreover, INGV-OE has several cameras recording images in the visible and infrared bands; they are located in Catania (ECV, $27 \mathrm{~km}$ from the summit craters), Milo (EMV, $11 \mathrm{~km}$ from the summit craters), Nicolosi (ENV and ENT, $15 \mathrm{~km}$ from the summit craters), Schiena dell'Asino (ESV, $5 \mathrm{~km}$ SE from the summit craters), Monte Cagliato (EMCT, $8 \mathrm{~km} \mathrm{E}$ from the summit craters), and La Montagnola (EMOV and EMOT, $3 \mathrm{~km}$ SE from the summit craters). The images of those cameras are used by the volcanologist on duty to monitor any variation of volcanic activity and estimate the eruption column height (Scollo et al., 2014).

\section{Lidar System}

An innovative Lidar system was developed in the frame of the VAMOS SEGURO project, with the aim of studying and forecasting volcanic ash plumes from Etna. The Lidar, named Aerosol Multi-Wavelength Polarization Lidar Experiment (AMPLE) and developed by the Consorzio Interuniversitario per le Scienze Fisiche della Materia (CNISM), is a compact multiwavelength Elastic/Raman scanning system with depolarization capability, suitable for mobile measurements and able to carry out 4-D (space and time) imaging of volcanic particles distributions, their optical properties and microphysical characterization. The AMPLE Lidar is equipped with a doubled and tripled Nd:YAG diode-pumped laser with a repetition rate of $1 \mathrm{kHz}$ and average optical power of $0.6 \mathrm{~W}$ at $355 \mathrm{~nm}, 1.5 \mathrm{~W}$ at $532 \mathrm{~nm}$, and $1 \mathrm{~W}$ at $1,064 \mathrm{~nm}$. The relative high repetition rate laser source increases the detectable signal dynamic range allowing to perform measurements even in the case of high density aerosol load, such as those ejected during massive explosive eruptions or heavy dust storm events. The receiving system is based on a $25 \mathrm{~cm}$ modified Cassegrain telescope. The detection system is able to measure both the elastic Lidar returns at $355 \mathrm{~nm}$ (parallel and crosspolarized signals) and the $\mathrm{N}_{2}$ Raman Lidar echoes at $386 \mathrm{~nm}$. Due to its modular configuration the system has been upgraded on 2016 with channels at $532 \mathrm{~nm}$ (parallel and cross-polarized signals) and the $\mathrm{N}_{2}$ Raman channel at $607 \mathrm{~nm}$. Each detected signal is acquired by a multi-channel scaler with a raw spatial resolution of $15 \mathrm{~m}$.

\footnotetext{
${ }^{1}$ http://www.vamosseguro.eu
}

In order to verify the accuracy of parameter measured by AMPLE Lidar system inter comparison measurements were performed with the EARLINET (European Aerosol Research Lidar Network) (Bösenberg et al., 2001, 2003) Lidar system MALIA (Multi-wavelength Aerosol LIdar Apparatus) located in Naples. MALIA is periodically calibrated for depolarization measurements through the technique proposed by Freudenthaler et al. (2009). Calibration methods and results are detailed in Wang et al. (2015). At present, the AMPLE system is part of the EARLINET network ${ }^{2}$ and it is devoted to special measurement campaigns at Etna volcano. The Lidar system was operated at the Istituto Nazionale di Astrofisica in Catania about $25 \mathrm{~km}$ away from the summit craters. Lidar derived aerosol properties are studied in terms of the boundaries of the observed layers, aerosol extinction $\left(\alpha_{A}\right)$, and backscattering $\left(\beta_{A}\right)$ coefficients profiles, their ratio (LR), and calibrated particle linear depolarization ratio $\left(\delta_{\mathrm{A}}\right)$.

The $\alpha_{A}$ coefficient was retrieved by means of the method introduced by Ansmann et al. (1990) from $\mathrm{N}_{2}$ Raman Lidar signal measured at $386 \mathrm{~nm}$ during night-time. The retrieval of the $\beta_{\mathrm{A}}$ coefficient at $355 \mathrm{~nm}$ from night-time observations was performed by using the Raman method (Ansmann et al., 1992) based on simultaneous detection of both elastic and $\mathrm{N}_{2}$ Raman Lidar echoes. In a different way, the retrieval of the $\beta_{A}$ coefficient at $355 \mathrm{~nm}$ from daytime measurements was obtained by using the Klett-Fernald algorithm (Klett, 1981; Fernald, 1984). The Elastic/Raman technique provides an independent estimation of $\beta_{\mathrm{A}}$ and $\alpha_{\mathrm{A}}$ vertical profiles; in this way the LR can be directly measured along the beam path. This parameter is essential in the optical properties retrieval and it is generally assumed to be known in the inversion procedure using the Klett-Fernald algorithm requiring a hypothesis on the LR value. The LR values choice should be carefully evaluated to prevent large uncertainty on the retrieved value of the backscattering coefficient. In our analysis the uncertainty due to a LR assumption was removed. For daytime observations, we fixed the LR values having as references the values of LR determined by the nearest time Raman measurements. The $\delta_{\mathrm{A}}$ values were obtained from the elastic Lidar profiles measured in the parallel and crosspolarized channels at $355 \mathrm{~nm}$ according to Biele et al. (2000) and Freudenthaler et al. (2009) inversion procedures. The depolarization of aerosol can be used to discriminate aerosol shape and to identify the presence of non-spherical particles with higher depolarization ratios (Gasteiger et al., 2011) in the atmospheric sample sounded by the Lidar. In our analysis the polarization Lidar technique was used to recognize the volcanic product and to distinguish the particles shape and thermodynamic phase in the emitted plume.

Due to the different gain of the detection channels or to the different optical transmission efficiency, the $\delta_{\mathrm{A}}$ calibration is essential since the uncertainty related to the particle depolarization ratio retrieval affects the accuracy of the derived parameters.

In order to calibrate the Lidar depolarization channels, we used a two-step procedure. The first step is the correction of

${ }^{2}$ https://www.earlinet.org 
gain ratio by means of a depolarizer plate placed in the receiver. The depolarizer plate makes the return light unpolarised and let us to calibrate the difference of gain between parallel and crosspolarized channels. However, since the light emitted from a laser is not completely polarized, optical components drawbacks also add depolarisation to the signal so calibration by depolarizer plate is not enough.

The second step is the correction of the depolarization caused by transmitting and receiving optical systems using pure molecular scattering. Since the depolarization ratio of atmospheric molecules is determined in the Lidar system using very narrow filters, pure molecular scattering profile (Behrendt and Nakamura, 2002) is used to calibrate the depolarization of AMPLE.

Finally, ash mass concentration $(\gamma)$ was evaluated using the $\delta_{\mathrm{A}}$ and LR profiles, measured in the observed plume and following the methodology of Tesche et al. (2009) and Ansmann et al. (2011) detailed in the work of Pisani et al. (2012), already applied by Scollo et al. (2012b, 2015).

\section{RESULTS}

\section{The December 14th-17th 2013 Etna Eruption}

Etna eruptions are mainly produced from the summit craters (e.g., Alparone et al., 2003; Behncke et al., 2006; Scollo et al., 2013) and from some fractures opened on the volcano flanks (e.g., Rittmann, 1973; Branca and Del Carlo, 2005). In late 2009 a new crater, the New South East Crater (NSEC), formed at the base of the eastern flank of the South East Crater (SEC) (e.g., Calvari et al., 2011) and became one of the most active and biggest crater in the recent eruptive story of Etna (Behncke et al., 2014) with 25 eruptive episodes between January 2011 and April 2012. The explosive activity of the SEC was mainly characterized by powerful lava fountains forming eruption columns that often reached the tropopause (Scollo et al., 2014).

The 14-17 December eruption at Etna was preceded by Strombolian activity accompanied by a gradual increase of volcanic tremors until 2 December, when the last lava fountain event of 2013 occurred (INGV-OE, 2013a). Ash emission and intense Strombolian activity characterized the period between 14 and 17 December, 2013 (INGV-OE, 2013b). This activity was well-recorded by the INGV-OE video surveillance system. On 14 December, there was a resumption of the explosive activity from the NSEC at 08:24 GMT with an ash emission event forming a thin volcanic plume reaching about $2 \mathrm{~km}$ a.s.l. high. After this explosion, a small vent opened on the edge of the NSEC, producing Strombolian activity forming a weak volcanic plume that was dispersed toward the East-South East. The activation of a new lava flow directed toward the Valle del Bove was observed at about 22:23 GMT. In the early morning of 15 December, two new vents opened on the NSEC flank at about 05:10 and 05:33 GMT, while Strombolian activity persisted with variable intensity. Both the explosive and effusive activity went on until 16 December when, at about 13:30 GMT, a new eruptive fracture opened on the lower part of the North-East flank (Figure 1a) that also formed a small lava flow well-visible during the night (Figure 1b). Explosive activity was clearly detected at 14:50 and 15:36 GMT from both the EMOV and EMOT cameras, located at about 2,500 $\mathrm{m}$ a.s.l., while the ECV camera showed a cloud cover above Catania (Figures 1c-h). Figure $\mathbf{2}$ shows the eruptive activity observed by EMOH, EMOT, and EMCT cameras during Lidar measurements. The videos highlighted two lava flows and a weak decrease of the explosive activity during the evening. The clockwise variations of tephra fallout, as it is shown by INGV-OE volcanic ash forecasts (Scollo et al., 2009), interested the South East and South flanks (Figure 3) of the volcano. Ash fallout reported in Acitrezza, Acicastello, and Catania ${ }^{3}$ and formed a thin tephra deposit. The explosive activity ended during the first hours of 17 December, 2013, while the lava flow finally stopped during the night between 18 and 19 December, 2013.

\section{Lidar Data}

Several zenith Lidar observations, with 1 min integration time, were performed on 16 December, 2013 when an eruptive cloud of ash, driven by winds in the South direction (Figure 3), was visible in Catania. Long time measurement at $355 \mathrm{~nm}$ were continuously performed from 10:45 to 17:33 GMT; during this time period three measurements lasting $30 \mathrm{~min}$ using a depolarizer for calibration of the depolarization were carried out. The analysis of each Lidar profile measured during the morning revealed fast moving atmospheric clouds mainly composed of water vapor $\left(\delta_{\mathrm{A}}<5 \%\right)$ at lower altitude $(<1,400 \mathrm{~m})$, while a slightly depolarizing layer $\left(5 \%<\delta_{\mathrm{A}}<10 \%\right)$ was visible between about 1,400 and $2,000 \mathrm{~m}$, suggesting the presence of irregular particles in the atmosphere. The upper layer was stable in the altitude range. This detected layer could result from water vapor cloud and volcanic ash mixture. In the data inversion procedure for this layer, we used a LR of 50 sr, as determined by the closest Elastic/Raman measurement. Nevertheless, below 1,400 m we used a smaller LR value (30 sr), according to low cloud presence together with a contribution of volcanic particles. Diurnal observations showed a decrease with time in the measured backscattering below $2,000 \mathrm{~m}$; this is probably due to the waning of the explosive activity at the NSEC as also qualitatively visible in the images taken by video cameras. After 15:36 GMT, a new layer with $\delta_{\mathrm{A}}>10 \%$ was clearly visible in the backscatter profiles between 3 and $4 \mathrm{~km}$. This new layer might be interpreted as volcanic ash coming from the new eruptive fracture opened on the lower North-East Side of the NSEC flank, producing a small lava flow detected by camera and visual observations. In Figure 4 the map of the range corrected Lidar signals (RCS) for those measurements performed on 16 December, 2013 from 16:30 to 17:30 GMT, with a spatial resolution of $15 \mathrm{~m}$ and a temporal resolution of $60 \mathrm{~s}$, is reported. The figure highlights both the first layer due to diurnal emission below $2 \mathrm{~km}$ of altitude and the second more depolarizing volcanic layer between 3 and $4 \mathrm{~km}$.

Raman measurements were performed since 16:30 GMT and allowed to detect, for the first time, the LR profiles of the volcanic

${ }^{3}$ www.ct.ingv.it 

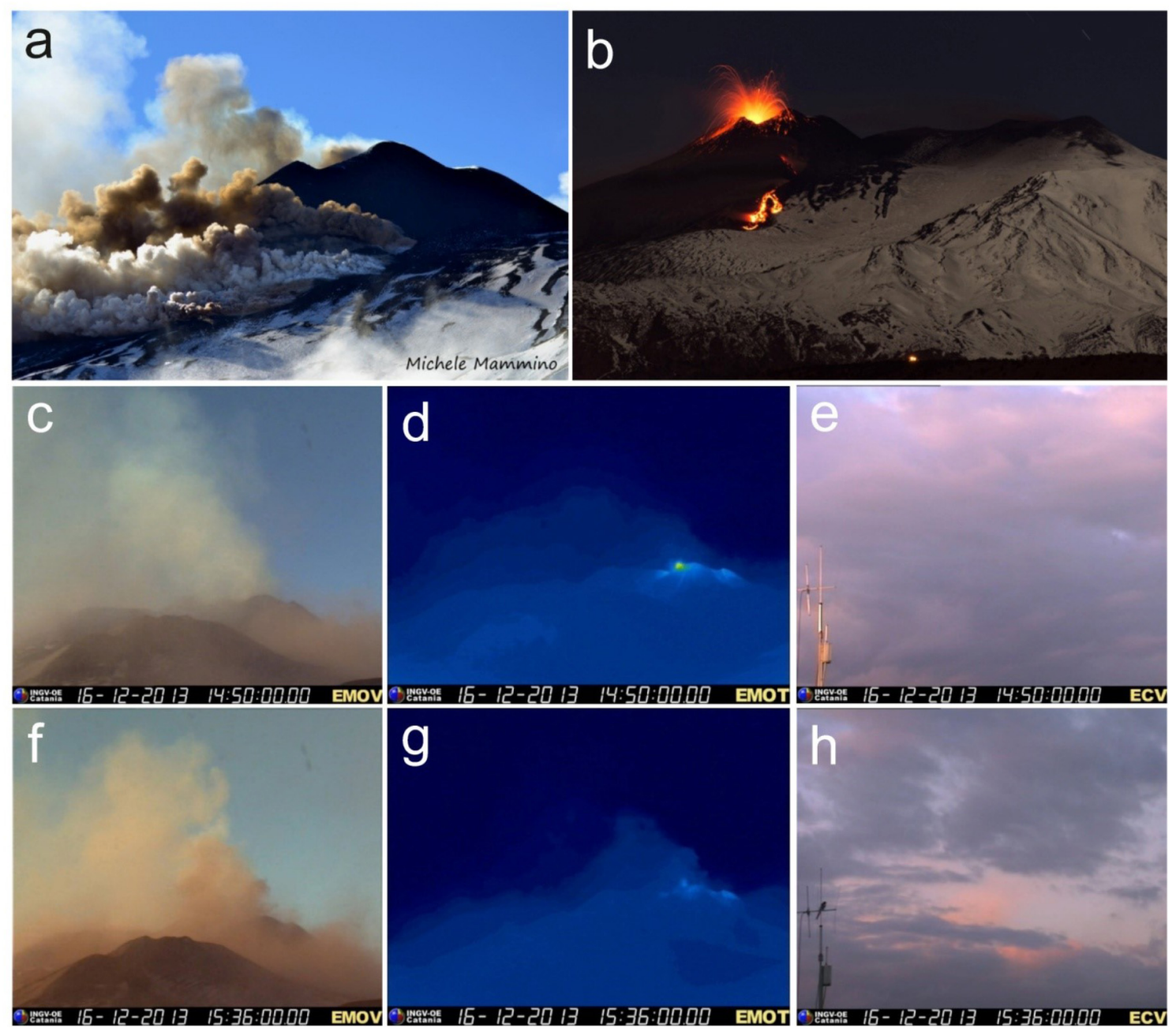

FIGURE 1 | Explosive activity during 16 December, 2016. (a) Photo of the eruptive fissures opened at about 13:00 GMT taken by Michele Mammino; (b) Photo of the lava flow coming from the same fracture taken by Francesco Mangiaglia; strombolian activity retrieved at 14:50 GMT by (c) EMOV, (d) EMOT and (e) ECV cameras; and at 15:36 GMT retrieved by (f) EMOV, (g) EMOT, and (h) ECV cameras.

plume near Mount Etna's summit craters. Figure 5 reports the Lidar profiles of $\beta_{\mathrm{A}}, \alpha_{\mathrm{A}}, \mathrm{LR}$, and $\delta_{\mathrm{A}}$ obtained from measurements carried out at 17:00 GMT. In order to enhance the signal to noise ratio, the Lidar profiles were reported with 15 min integration time; moreover, a binning procedure was performed on lidar signals in the data analysis, therefore the vertical resolution was reduced to $60 \mathrm{~m}$ for $\beta_{\mathrm{A}}$ and $\delta_{\mathrm{A}}$ profiles, while it was $180 \mathrm{~m}$ for $\alpha_{A}$ and LR profiles. Lidar measurements highlight two different signatures of fresh volcanic ash in the altitude ranges between 3,000-3,400 $\mathrm{m}$ and 3,400-4,100 $\mathrm{m}$. The $\delta_{\mathrm{A}}$ mean values in these layers resulted 49.7 and $43.5 \%$, respectively. The very high $\delta_{A}$ values measured along the vertical profile (up to $75 \pm 19 \%$ ) correspond to ash with highly irregular shape. This result could reflect the fragmentation of hot basaltic magma with low viscosity that produces juvenile ash with elongated shape cooling in the atmosphere.

Larger concentrations of ash particles were detected in the higher range of altitude $\left(5.5 \times 10^{-4} \mathrm{~g} / \mathrm{m}^{3}\right)$ with respect to the values in the lower one $\left(2.3 \times 10^{-4} \mathrm{~g} / \mathrm{m}^{3}\right)$. This is in agreement with larger LR mean values in the higher layer $(53 \mathrm{sr})$ compared to the one measured in the lower layer $\left(35 \mathrm{sr}\right.$ ). LR and $\delta_{\mathrm{A}}$ measured values were in agreement with the volcanic ash classification scheme at $355 \mathrm{~nm}$ showing LR values higher than $40 \mathrm{sr}$ and $\delta_{A}$ higher than 33\%, as reported by Groß et al. (2015). These values clearly indicate the presence of non-spherical particles and suggest a large fraction of glass and mineral aerosols. The $\delta_{\mathrm{A}}$ values, measured in the plume developed in the afternoon, are different from the values measured in the morning at lower altitude; this suggests a different shape of volcanic particles and reflects the increase of explosive activity in the afternoon.

The LR, $\delta_{\mathrm{A}}$, and $\gamma_{\mathrm{A}}$ averaged values in the layers resulting from the afternoon measurements of 16 December, 2013 are reported in Table 1. The mean properties inside each layer changed during the time, highlighting a temporal evolution of the vertical distribution of the aerosol load and possible changes in its composition. The $\delta_{\mathrm{A}}$ values of the higher layer rapidly 


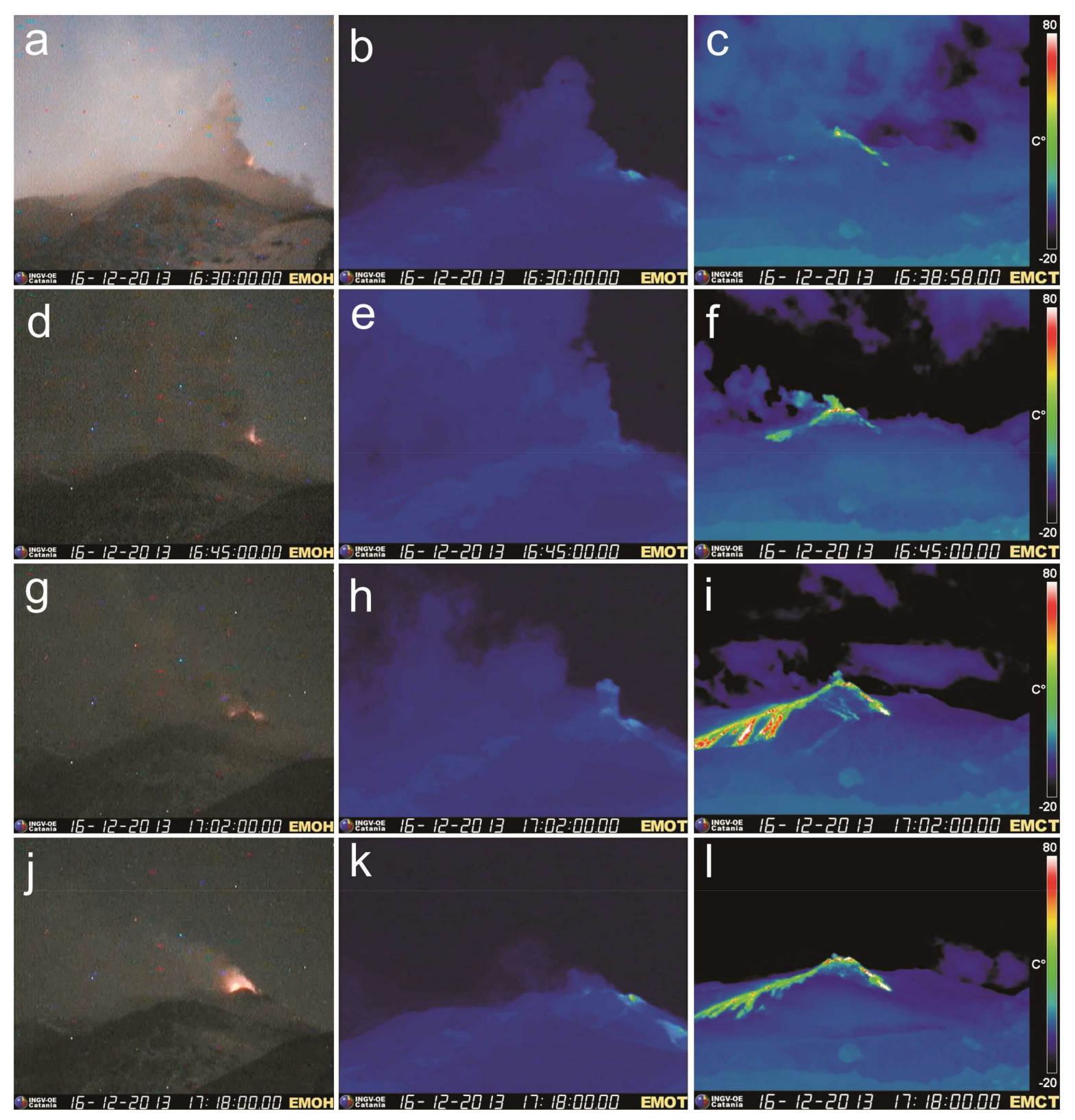

FIGURE 2 | Explosive activity retrieved by EMOH (a,d,g,j), EMOT (b,e,h,h), and EMCT (c,f,i, l) cameras on 16 December, 2013 during the Lidar measurements.

increased with time going up to $44 \%$, while, LR resulted in about 48 sr due to the presence of volcanic ash in the layer and it did not change with time after the 16:45 GMT. The lack of significant variability of the LR in the observed volcanic plume suggests the presence of the same type of aerosol. Despite the high depolarizing nature of the observed plume, the multiple scattering influence in our measurement was not relevant due to both the short distance of the plume from the Lidar and the low values of the optical depth (OD) measured in the plume $<0.1$.

In the Planetary Boundary Layer (PBL) whose top height was located at $1,100 \mathrm{~m}$ of altitude during the time measurements, we observed a slightly decrease in the LR values with time, which suggests a change in the dominant aerosol typology. The observed behavior could be related to the contribution of the diurnal ash, located in the range $1,400-2,000 \mathrm{~m}$, which feels across the PBL and mixed up with local marine aerosol. The mixed aerosol in the PBL shows lower $\delta_{\mathrm{A}}$ values thus suggesting a more pronounced spherical particle shape. Finally, the larger LR values obtained in the range 1,100-3,000 $\mathrm{m}$ fit well with the higher values obtained in volcanic ash plumes (Groß et al., 2012), when volcanic sulfate particles were mixed with anthropogenic particles (Navas-Guzmán et al., 2013). 


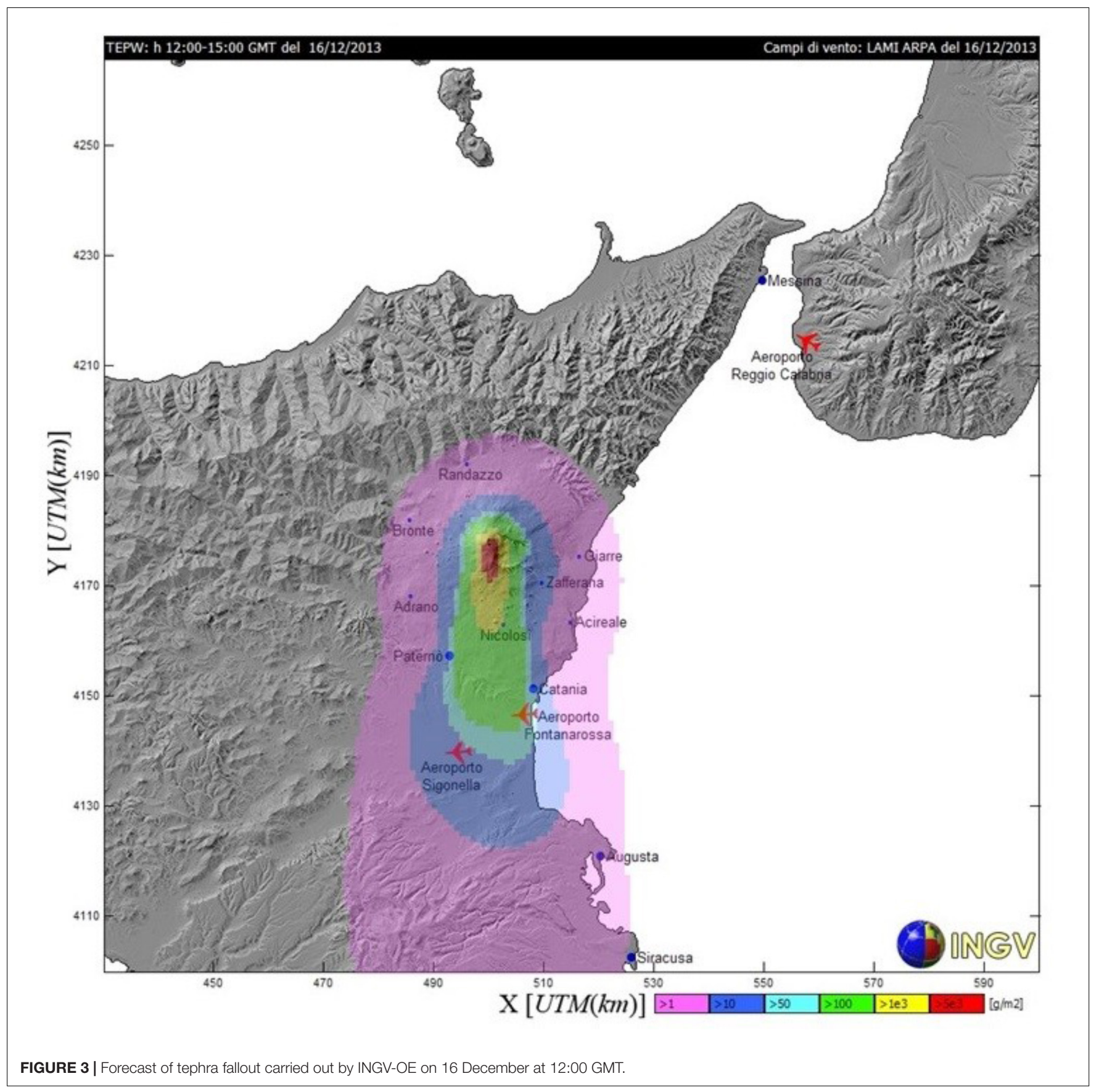

\section{DISCUSSION AND CONCLUSION}

Lidar data acquired on 16 December, 2013 have shown how Lidar observations can provide real time detection of volcanic plume emission and can be very useful for monitoring its evolution with time. Lidar measurements were able to capture the complex dynamics of the eruptive event by tracking the variations of ash emissions during the explosive activity with time. Data highlighted two different phases of the eruptive activity: from 10:45 to 15:05 GMT we observed a volcanic layer which was related to the explosive activity that occurred early in the morning while in the afternoon, after 15:36 GMT, Lidar measurements captured particles coming from both the explosive activity and the eruptive fracture developed at about 13:30 GMT. The combination of values and variation of the backscatter coefficient and the LR and the aerosol depolarization ratio also showed variations on particles features in the atmosphere.

Vertical profiles of aerosol backscattering coefficient were able to track in time the decrease of the explosive activity of the fissure developed late in the morning and located at the North East side of the NSEC. Aerosol depolarization ratio $\delta_{\mathrm{A}}$ allowed to evaluate the sphericity of the volcanic cloud particles. Its variation with 

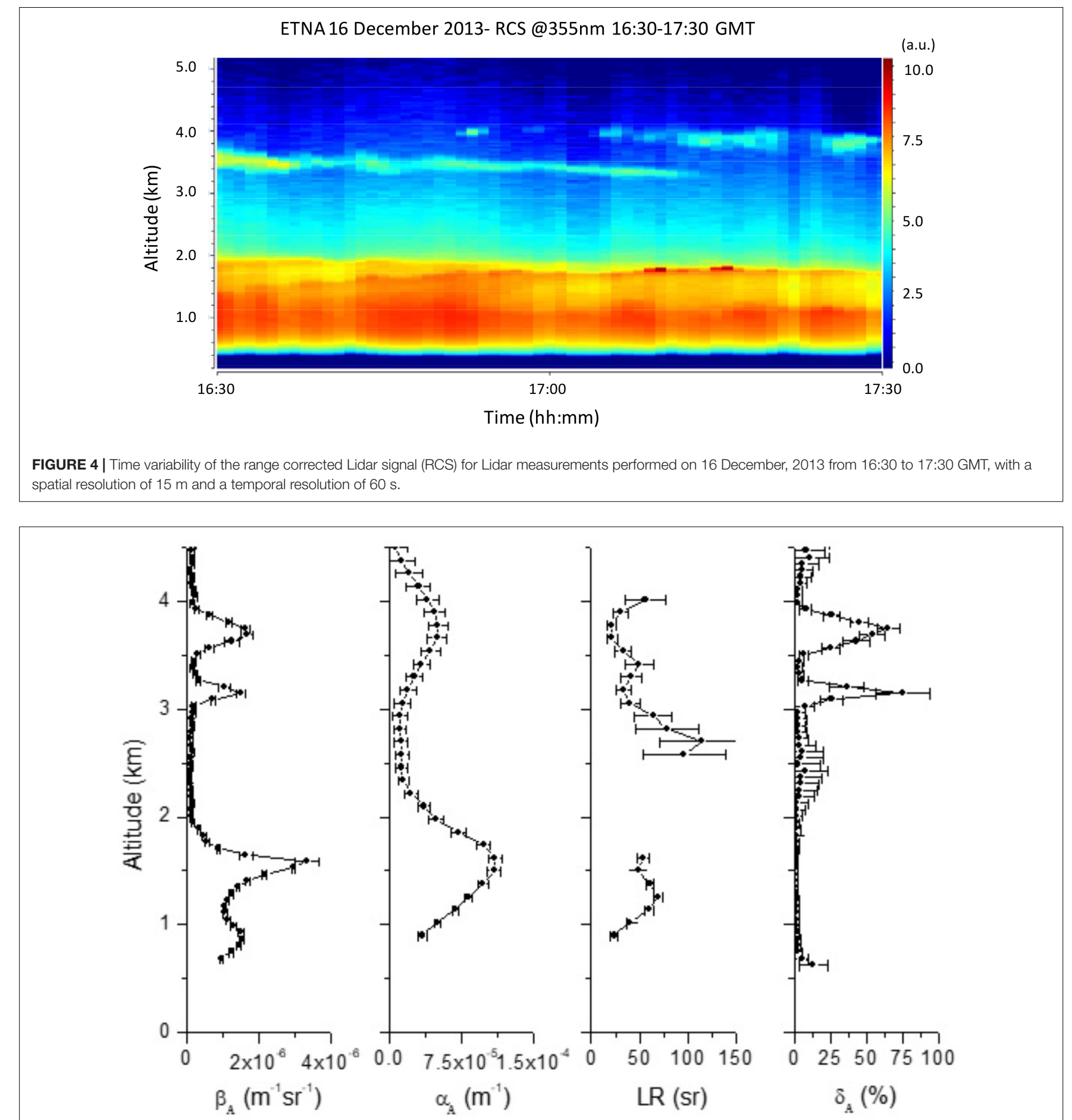

FIGURE 5 | Lidar profiles obtained from measurements carried out at 17:00 GMT and corresponding to $15 \mathrm{~min}$ time integration. Vertical resolution is $60 \mathrm{~m}$ for $\beta_{A}$, and $\delta_{A}, 180 \mathrm{~m}$ for $\alpha_{A}$ and $L R$.

time suggests a modification of the aerosol shape probably related to physical interactions between volcanic ash particles and water vapor, a dominant component during most explosive volcanic eruptions, strongly affecting the microphysical evolution of ash (Lathem et al., 2011). In fact, ash uptakes water efficiently via adsorption and nucleates into cloud drops, whose more spherical shape can justify the observed values of $\delta_{\mathrm{A}}$. Larger $\delta_{\mathrm{A}}$ values obtained in the afternoon measurement in an upper plume clearly indicate the presence of non-spherical particles and suggest the presence of a larger fraction of glass and mineral aerosols. 
TABLE 1 | Timetable of aerosol parameters [Lidar Ratio (LR), aerosol depolarization $\delta_{A}$, and concentration $\gamma$ ) averaged in the observed layers.

\begin{tabular}{|c|c|c|c|c|}
\hline $\begin{array}{l}\text { Time (hh:mm) } \\
\text { GMT }\end{array}$ & Range (m) & LR (sr) & $\delta(\%)$ & $\gamma\left(\mathrm{mg} / \mathrm{m}^{3}\right) \times 10^{-2}$ \\
\hline \multirow[t]{4}{*}{$16: 30-16: 45$} & $<1100$ & $51.5 \pm 3.5$ & $2.04 \pm 0.20$ & $1.5 \pm 0.2$ \\
\hline & $1100-2000$ & $75.3 \pm 2.5$ & $1.07 \pm 0.09$ & $0.5 \pm 0.2$ \\
\hline & 2000-3000 & $57.1 \pm 29.0$ & $0.89 \pm 0.13$ & $0.04 \pm 0.09$ \\
\hline & $3000-4100$ & $45.1 \pm 4.1$ & $12.19 \pm 1.10$ & $10.7 \pm 4.4$ \\
\hline \multirow[t]{5}{*}{$16: 45-17: 00$} & $<1100$ & $48.5 \pm 4.0$ & $2.52 \pm 0.20$ & $2.4 \pm 0.3$ \\
\hline & $1100-2000$ & $70.6 \pm 2.8$ & $1.57 \pm 0.07$ & $2.8 \pm 0.3$ \\
\hline & $2000-3000$ & $72.3 \pm 24$ & $5.69 \pm 0.75$ & $1.9 \pm 0.2$ \\
\hline & $3000-3500$ & $30.1 \pm 6.7 \quad 48.2 \pm 7.0^{*}$ & $15.54 \pm 2.10 \quad 18.87 \pm 2.44^{*}$ & $13.0 \pm 4.5 \quad 13.9 \pm 5.0^{*}$ \\
\hline & $3500-4100$ & $58.2 \pm 17.1$ & $26.06 \pm 3.72$ & $16.0 \pm 5.9$ \\
\hline \multirow[t]{5}{*}{$17: 00-17: 15$} & $<1100$ & $48.3 \pm 3.3$ & $2.05 \pm 0.12$ & $2.1 \pm 0.3$ \\
\hline & 1100-2000 & $71.8 \pm 2.3$ & $1.24 \pm 0.05$ & $1.1 \pm 0.2$ \\
\hline & 2000-3000 & $69.9 \pm 16.0$ & $3.91 \pm 0.49$ & $1.0 \pm 0.2$ \\
\hline & $3000-3400$ & $34.9 \pm 3.6$ & $49.67 \pm 8.99 \quad 46.34 \pm 9.05^{*}$ & $22.8 \pm 6.8$ \\
\hline & $3400-4100$ & $53.3 \pm 16.2$ & $43.47 \pm 9.56$ & $55.0 \pm 17.7$ \\
\hline \multirow[t]{4}{*}{$17: 15-17: 30$} & $<1100$ & $44.3 \pm 3.7$ & $2.97 \pm 0.11$ & $4.3 \pm 0.6$ \\
\hline & $1100-2000$ & $78.3 \pm 3.8$ & $2.31 \pm 0.24$ & $4.7 \pm 0.5$ \\
\hline & $2000-3000$ & $75.3 \pm 24.0$ & $13.32 \pm 0.51$ & $4.6 \pm 0.4$ \\
\hline & $3000-4100$ & $48.1 \pm 5.6$ & $44.13 \pm 4.76$ & $38.8 \pm 13.8$ \\
\hline
\end{tabular}

Values with * correspond to values averaged in the range 3000-4100 $\mathrm{m}$.

Mean LR values, measured for the first time near the Etna summit craters, matched with values reported in the literature for volcanic ash when volcanic sulfate particles are mixed with anthropogenic particles (Navas-Guzmán et al., 2013). The obtained results suggest a large amount of $\mathrm{SO}_{2}$ released from the volcano in the ash, according to $\mathrm{SO}_{2}$ flux emitted from Etna that reached peak values greater than $15,000 \mathrm{t} / \mathrm{d}$ on 16 December (INGV - Bollettino settimanale Etna del 24/12/2013 Rep. $\mathrm{N}^{\circ}$ $52 / 2013)$. The $\mathrm{SO}_{2}$ presence in the plume is also confirmed by the IASI and GOME 2 satellite images ${ }^{4}$ in the UV - visible and infrared wavelengths, respectively.

Daily forecasts run by INGV-OE confirmed the movement of the volcanic plume from South East toward the South in the night between 15 and 16 December. The airspace around Etna was accordingly closed in the evening of 15 December 2013 and dozens of departures were canceled at the international airport in Catania, with several flights diverted toward Palermo airport. However, Lidar measurements carried out at the INAF, in Catania, only $10 \mathrm{~km}$ far from the airport, showed the highest concentration value of $5.5 \times 10^{-4} \mathrm{~g} / \mathrm{m}^{3}$, measured at altitudes between 3,000 and $4,000 \mathrm{~m}$, i.e., below the risk threshold for aircrafts $\left(2 \times 10^{-3} \mathrm{~g} / \mathrm{m}^{3}\right)$.

It should be noted that our study is based on observations carried out using a one wavelength Lidar system with Elastic/Raman and polarization capability. Due to the lack of multi-wavelengths observations, important parameters for particles characterization have not been estimated. Particle shape information derived from the aerosol depolarization values in combination with aerosol optical properties measured at many wavelengths allow the aerosol microphysical characterization and

${ }^{4}$ http://sacs.aeronomie.be both size distribution and mass concentration retrieval. The extended observation capability of the system, upgraded in 2016 with the implementation of the $532 \mathrm{~nm}$ channels (parallel and cross-polarized) and the corresponding $\mathrm{N}_{2}$ Raman channel at $607 \mathrm{~nm}$, has already allowed us to improve our capability to evaluate optical particles near active craters. Lidar measurements carried out near active volcanoes are, however, uncommon although they could really improve our understanding on plume transport and evolution of volcanic particles. The elastic channel at 1,064 $\mathrm{nm}$ will be implemented in the next future opening new prospects for the use of Lidars in the volcanic plume survey.

\section{AUTHOR CONTRIBUTIONS}

$\mathrm{AB}$ and SS were responsible for the conceptual design of the work and lead the writing and compilation of figures and tables. SS and MC are responsible of volcanological observations. GL, SS, and RS performed the Lidar measurements, AS, AB, XW, and NS performed the Lidar data analysis and interpretation. GL and SS manage the Lidar system at Etna. All authors have given substantial contributions to the discussion of the article and approved the submitted version of the manuscript and thereby agreed to be accountable for all aspects of the work, ensuring that questions related to the accuracy or integrity of any part of the work are appropriately investigated and resolved.

\section{FUNDING}

The financial support for EARLINET-ASOS by the European Commission in the Sixth Framework Programme under grant 
RICA-025991 and for ACTRIS in the Seventh Framework Programme under Grant Agreement No. 262254 are gratefully acknowledged. This work was funded by the VAMOS SEGURO project, Programma di Cooperazione Transfrontaliera Italia - Malta 2007-2013, A1.2.3-62, Obiettivo Specifico 2.3.

\section{REFERENCES}

Ackermann, J. (1998). The extinction-to-backscatter ratio of tropospheric aerosol: a numerical study. J. Atmos. Oceanic Technol. 15, 1043-1050. doi: 10.1175/15200426(1998)015<1043:TETBRO>2.0.CO;2

Alparone, S., Andronico, D., Lodato, L., and Sgroi, T. (2003). Relationship between tremor and volcanic activity during the Southeast Crater eruption on Mount Etna in early 2000. J. Geophys. Res. 108:2241. doi: 10.1029/2002JB 001866

Ansmann, A., Riebesell, M., Wandinger, U., Weitkamp, C., Voss, E., Lahmann, W., et al. (1992). Combined raman elastic-backscatter LIDAR for vertical profiling of moisture, aerosol extinction, backscatter, and LIDAR ratio. Appl. Phys. B 55:18. doi: 10.1007/BF00348608

Ansmann, A., Riebesell, M., and Weitkamp, C. (1990). Measurement of atmospheric aerosol extinction profiles with a Raman lidar. Opt. Lett. 15, 746-748. doi: 10.1364/OL.15.000746

Ansmann, A., Tesche, M., Groß, S., Freudenthaler, V., Seifert, P., Hiebsch, A., et al. (2010). The 16 April 2010 major volcanic ash plume over central Europe: EARLINET lidar and AERONET photometer observations at Leipzig and Munich, Germany. Geophys. Res. Lett. 37:L13810. doi: 10.1029/2010GL 043809

Ansmann, A., Tesche, M., Groß, S., Freudenthaler, V., Seifert, P., Hiebsch, A., et al. (2011). Ash and fine-mode particle mass profiles from EARLINETAERONET observations over central Europe after the eruptions of the Eyjafjallajokull volcano in 2010. J. Geophys. Res. Atmos. 116:L13810. doi: 10. 1029/2010GL043809

Ayris, P. M., and Delmelle, P. (2012). The immediate environmental effects of tephra emission. Bull. Volcanol. 74, 1905-1936. doi: 10.1007/s00445-012-06545

Ayris, P. M., Delmelle, P., Cimarelli, C., Maters, E. C., Suzuki, Y. J., and Dingwell, D. B. (2014). HCl uptake by volcanic ash in the high temperature eruption plume: mechanistic insights. Geochimica et Cosmochimica Acta 144, 188-201. doi: 10.1016/j.gca.2014.08.028

Azzopardi, F., Raymond, E., Prestifilippo, M., Scollo, S., and Coltelli, M. (2013). The effect of Etna volcanic ash clouds on the maltese islands. J. Volcanol. Geother. Res. 260, 13-26. doi: 10.1016/j.jvolgeores.2013.04.019

Balis, D., Koukouli, M. E., Siomos, N., Dimopoulos, S., Mona, L., Pappalardo, G., et al. (2016). Validation of ash optical depth and layer height retrieved from passive satellite sensors using EARLINET and airborne lidar data: the case of the Eyjafjallajokull eruption. Atmos. Chem. Phys. 16, 5705-5720. doi: 10.5194/ acp-16-5705-2016

Behncke, B., Branca, S., Corsaro, R. A., De Beni, E., Miraglia, L., and Proietti, C. (2014). The 2011-2012 summit activity of Mount Etna: birth, growth and products of the new SE crater. J. Volcanol. Geotherm. Res. 270, 10-21. doi: 10.1016/j.jvolgeores.2013.11.012

Behncke, B., Neri, M., Pecora, E., and Zanon, V. (2006). The exceptional activity and growth of the Southeast Crater, Mount Etna (Italy), between 1996 and 2001. Bull. Volcanol. 69, 149-173. doi: 10.1007/s00445-006-0061-x

Behrendt, A., and Nakamura, T. (2002). Calculation of the calibration constant of polarization lidar and its dependency on atmospheric temperature. Opt. Express 10, 805-817. doi: 10.1364/OE.10.000805

Biele, J., Beyerle, G., and Baumgarten, G. (2000). Polarization lidar: corrections of instrumental effects. Opt. Express 7, 427-435. doi: 10.1364/OE.7.000427

Bonadonna, C., Folch, A., Loughlin, S., and Puempel, H. (2012). Future developments in modelling and monitoring of volcanic ash clouds: outcomes from the first IAVCEI-WMO workshop on Ash dispersal forecast and civil aviation. Bull. Volcanol. 74, 1-10. doi: 10.1007/s00445-0110508-6

\section{ACKNOWLEDGMENTS}

We thank Michele Prestifilippo who maintains the forecasting system of volcanic ash dispersal at INGV-OE. We also thank Emilio Biale and Michele Prestifilippo for the use of images coming from the INGV-OE camera network.

Bonadonna, C., Genco, R., Gouhier, M., Pistolesi, M., Cioni, R., Alfano, F., et al. (2011). Tephra sedimentation during the 2010 Eyjafjallajokull eruption (Iceland) from deposit, radar, and satellite observations. J. Geophys. Res. Solid Earth 116:B12202. doi: 10.1029/2011JB008462

Bonadonna, C., Pistolesi, M., Cioni, R., Degruyter, W., Elissondo, M., and Baumann, V. (2015). Dynamics of wind-affected volcanic plumes: the example of the 2011 Cordón Caulle eruption, Chile. J. Geophys. Res. Solid Earth 120, 2242-2261. doi: 10.1002/2014JB011478

Bösenberg, J., Ansmann, A., Baldasano, J. M., Balis, D., Böckmann, C., Calpini, B., et al. (2001). "EARLINET: a european aerosol research lidar network in advanced in laser remote sensing, of the atmosphere," in Selected Papers of the 20th International Laser Radar Conference, eds A. Dabas, C. Loth, and J. Pelon (Palaiseau: Ecole Polytechnique), 155-158.

Bösenberg, J., Mattias, V., Amodeo, A., Amoiridis, V., Ansmann, A., Baldasano, J. M., et al. (2003). A European aerosol research lidar networkto establish an aerosol climatology. Max Planck Institutfür Meteorol. Tech. Rep. 348, $135-137$.

Branca, S., and Del Carlo, P. (2005). Types of eruptions of Etna volcano AD 1670-2003: implications for short-term eruptive behavior. Bull. Volcanol. 67, 732-742. doi: 10.1007/s00445-005-0412-z

Calvari, S., Salerno, G. G., Spampinato, L., Gouhier, M., La Spina, A., Pecora, E., et al. (2011). An unloading foam model to constrain Etna's 11-13 January 2011 lava fountaining episode. J. Geophys. Res. 116:B11207. doi: 10.1029/ 2011JB008407

Corradini, S., Montopoli, M., Guerrieri, L., Ricci, M., Scollo, S., and Merucci, L. (2016). A multi-sensor approach for volcanic ash cloud retrieval and Eruption characterization: the 23 November 2013 Etna Lava fountain. Remote Sens. 8:58. doi: $10.3390 /$ rs8010058

Delmelle, P. (2003). Environmental impacts of tropospheric volcanic gas plumes. Geol. Soc. Lond. Spec. Pub. 213, 381-399. doi: 10.1144/GSL.SP.2003.213.01.23

Delmelle, P., Stix, J., Baxter, P., Garcia-Alvarez, J., and Barquero, J. (2002). Atmospheric dispersion, environmental effects and potential health hazard associated with the low altitude gas plume of Masaya volcano. Nicaragua. Bull. Volcanol. 64, 423-434. doi: 10.1007/s00445-002-0221-6

Fernald, F. G. (1984). Analysis of the atmospheric lidar observations; some comments. Appl. Opt. 23, 652-653. doi: 10.1364/AO.23.000652

Freudenthaler, V., Esselborn, M., Wiegner, M., Heese, B., Tesche, M., Ansmann, A., et al. (2009). Depolarization ratio profiling at several wavelengths in pure Saharan dust during SAMUM 2006. Tellus 61B, 165-179. doi: 10.1111/j.16000889.2008.00396.x

Gasteiger, J., Groß, S., Freudenthaler, V., and Wiegner, M. (2011). Volcanic ash from Iceland over Munich: mass concentration retrieved from ground-based remote sensing measurements. Atmos. Chem. Phys. 11:2209e2223. doi: 10.5194/ acp-11-2209-2011

Groß, S., Freudenthaler, V., Wiegner, M., Gasteiger, J., Geiß, A., and Schnell, F. (2012). Dual-wavelength linear depolarization ratio of volcanic aerosols: Lidar measurements of the Eyjafjallajökull plume over Maisach, Germany. Atmos. Environ. 48, 85-96. doi: 10.1016/j.atmosenv.2011.06.017

Groß, S., Freudenthaler, V., Wirth, M., and Weinzierl, B. (2015). Towards an aerosol classification scheme for future EarthCARE lidar observations and implications for research needs. Atmos. Sci. Lett. 16, 77-82. doi: 10.1002/asl2. 524

Gudmundsson, M. T., Thordarson, T., Hoskuldsson, A., Larsen, G., Bjornsson, H., Prata, F. J., et al. (2012). Ash generation and distribution from the Aprile May 2010 eruption of Eyjafjallajokull. Icel. Sci. Rep. 2:572. doi: 10.1038/srep 00572

Guffanti, M., Ewert, J. W., Gallina, G. M., Bluth, G. J. S., and Swanson, G. L. (2005). Volcanic-ash hazard to aviation during the 2003-2004 eruptive activity of 
anatahan volcano, commonwealth of the Northern Mariana Islands. J. Volcanol. Geoth. Res. 146, 241-255. doi: 10.1016/j.jvolgeores.2004.12.011

Hervo, M., Quennehen, B., Kristiansen, N. I., Boulon, J., Stohl, A., Fréville, P., et al. (2012). Physical and optical properties of 2010 Eyjafjallajökull volcanic eruption aerosol: ground-based, Lidar and airborne measurements in France. Atmos. Chem. Phys. 12, 1721-1736. doi: 10.5194/acp-12-17212012

Horwell, C. J. (2007). Grain size analysis of volcanic ash for the rapid assessment of respiratory health hazard. J. Environ. Monit. 9, 1107-1115. doi: 10.1039/ b710583p

INGV-OE (2013a). BollettinoEtna20131202. Rep. 50/2013. Available at: http:// www.ct.ingv.it/it/rapporti/multidisciplinari.html?start=465

INGV-OE (2013b). BollettinoEtna20131217. Rep. 51/2013. Available at: http:// www.ct.ingv.it/it/rapporti/multidisciplinari.html?start $=465$

Klett, J. D. (1981). Stable analytical inversion solution for processing lidar returns. Appl. Opt. 20, 211-220. doi: 10.1364/AO.20.000211

Kokkalis, P., Papayannis, A., Amiridis, V., Mamouri, R. E., Veselovskii, I., Kolgotin, A., et al. (2013). Optical, microphysical, mass and geometrical properties of aged volcanic particles observed over Athens, Greece, during the Eyjafjallajökull eruption in April 2010 through synergy of Raman lidar and sunphotometer measurements. Atmos. Chem. Phys. 13, 9303-9320. doi: 10.5194/acp-13-93032013

Kueppers, U., Cimarelli, C., Hess, K., Taddeucci, J., Wadsworth, F. B., and Dingwell, D. B. (2014). The thermal stability of Eyjafjallajökull ash versus turbine ingestion test sands. J. Appl. Volcanol. 3:4. doi: 10.1186/2191-50 40-3-4

Lathem, T. L., Kumar, P., Nenes, A., Dufek, J., Sokolik, I. N., Trail, M., et al. (2011). Hygroscopic properties of volcanic ash Geophys. Res. Lett. 38:L11802. doi: 10.1029/2011GL047298

Marenco, F., and Hogan, R. J. (2011). Determining the contribution of volcanic ash and boundary layer aerosol in backscatter lidar returns: a three-component atmosphere approach. J. Geophys. Res. Atmos. 116:D00U06. doi: 10.1029/ 2010jd015415

Marenco, F., Johnson, B., Turnbull, K., Newman, S., Haywood, J., Webster, H., et al. (2011). Airborne lidar observations of the 2010 Eyjafjallajokull volcanic ash plume. J. Geophys. Res. 116:D00U05. doi: 10.1029/2011JD 016396

Mereu, L., Scollo, S., Mori, S., Boselli, A., and Leto, G. (2018). Maximum-likelihood retrieval of volcanic ash concentration and particle size from ground-based scanning Lidar. IEEE Trans. Geosci. Remote Sens. 1-19. doi: 10.1109/TGRS. 2018.2826839

Miffre, A., David, G., Thomas, B., Rairoux, P., Fjaeraa, A. M., Kristiansen, N. I., et al. (2011). Volcanic aerosol optical properties and phase partitioning behavior after long-range advection characterized by UVLidar measurements. Atmos. Environ. 48, 76-84. doi: 10.1016/j.atmosenv.2011. 03.057

Miller, T. P., and Casadevall, T. J. (2000). "Volcanic ash hazards to aviation," in Encyclopedia of Volcanoes, eds H. Sigurdsson, B. F. Houghton, S. R. McNutt, H. Rymer, and J. Stix (San Diego: Academic Press), 915-930.

Mona, L., Amodeo, A., D’Amico, G., Giunta, A., Madonna, F., and Pappalardo, G. (2012). Multi-wavelength raman lidar observations of the Eyjafjallajökull volcanic cloud over Potenza, southern Italy. Atmos. Chem. Phys. 12:2229e2244. doi: 10.5194/acp-12-2229-2012

Müller, D., Ansmann, A., Mattis, I., Tesche, M., Wandinger, U., Althausen, D., et al. (2007). Aerosol-type-dependent lidar ratios observed with Raman lidar. J. Geophis. Res. Atmos. 112:D16202. doi: 10.1029/2006JD008292

Navas-Guzmán, F., Muller, D., Bravo-Aranda, J. A., Guerrero-Rascado, J. L., Granados-Munoz, M. J., Perez-Ramírez, D., et al. (2013). Eruption of the Eyjafjallajokull Volcano in spring 2010: multiwavelength Raman lidar measurements of sulphate particles in the lower troposphere. J. Geophys. Res. Atmos. 118, 1804-1813. doi: 10.1002/jgrd.50116

Papayannis, A., Mamouri, R. E., Amiridis, V., Giannakaki, E., Veselovskii, P., Kokkalis, I., et al. (2012). Optical properties and vertical extension of aged ash layers over the Eastern Mediterranean as observed by Raman lidars during the Eyjafjallajökull eruption in May 2010. Atmos. Environ. 48, 56-65. doi: 10.1016/ j.atmosenv.2011.08.037

Pappalardo, G., Mona, L., D’Amico, G., Wandinger, U., Adam, M., Amodeo, A., et al. (2013). A Four-dimensional distribution of the 2010 Eyjafjallajökull volcanic cloud over Europe observed by EARLINET, Atmos. Chem. Phys. 13, 4429-4450. doi: 10.5194/acp-13-4429-2013

Pisani, G., Boselli, A., Coltelli, M., Leto, G., Pica, G., Scollo, S., et al. (2012). Lidar calibrated depolarization measurement of fresh volcanic ash from Mt. Etna. Atmos. Environ. 62, 34-40. doi: 10.1016/j.atmosenv.2012.08.015

Ripepe, M., Bonadonna, C., Folch, A., Delle Donne, D., Lacanna, G., Marchetti, E., et al. (2013). Ash-plume dynamics and eruption source parameters by infrasound and thermal imagery: the 2010 Eyjafjallajokull eruption. Earth Planet. Sci. Lett. 366, 112-121. doi: 10.1016/j.epsl.2013.02.005

Rittmann, A. (1973). Structure and evolution of Mount Etna. Philos. Trans. R. Soc. Lond. A 274, 5-16. doi: 10.1098/rsta.1973.0021

Robock, A., and Oppenheimer, C. (eds) (2003). Volcanism and the Earth's Atmosphere. Geophysical Monograph 139. Washington, DC: American Geophysical Union, doi: 10.1029/GM139

Sassen, K., Zhu, J., Webley, P., Dean, K., and Cobb, P. (2007). Volcanic ash plume identification using polarization lidar: augustine eruption, Alaska. Geohys. Rev. Lett. 34:L08803. doi: 10.1029/2006GL027237

Scollo, S., Boselli, A., Coltelli, M., Leto, G., Pisani, G., Prestifilippo, M., et al. (2015). Volcanic ash concentration during the 12 August 2011 Etna eruption. Geophys. Res. Lett. 42, 2634-2641. doi: 10.1002/2015GL063027

Scollo, S., Coltelli, M., Bonadonna, C., and Del Carlo, P. (2013). Tephra hazard assessment at Mt. Etna (Italy). Nat. Hazards Earth Syst. Sci. 13, 3221-3233. doi: 10.5194/nhess- 13-3221-2013

Scollo, S., Boselli, A., Coltelli, M., Leto, G., Pisani, G., Spinelli, N., et al. (2012a). Monitoring Etna volcanic plumes using a scanning lidar. Bull. Volcanol. 74, 2382-2395. doi: 10.1007/s00445-012-0669-y

Scollo, S., Kahn, R. A., Nelson, D. L., Coltelli, M. D., Diner, J., Garay, M. J., et al. (2012b). MISR observations of Etna volcanic plumes. J. Geophys. Res. 117:D06210. doi: 10.1029/2011JD016625

Scollo, S., Prestifilippo, M., Pecora, E., Corradini, S., Merucci, L., Spata, G., et al. (2014). Eruption column height estimation of the 2011-2013 Etna lava fountains. Ann. Geophys. 57, 1-5. doi: 10.4401/ag-6396

Scollo, S., Prestifilippo, M., Spata, G., D’Agostino, M., and Coltelli, M. (2009). Monitoring and forecasting Etna volcanic plumes. Nat. Hazards Earth Syst. Sci. 9, 1573-1585. doi: 10.5194/nhess-9-1573-2009

Sicard, M., Guerrero-Rascado, J. L., Navas-Guzmán, F., Preißler, J., Molero, F., Tomás, S., et al. (2012). Monitoring of the Eyjafjallajökull volcanic aerosol plume over the Iberian Peninsula by means of four EARLINET lidar stations. Atmos. Chem. Phys. 12, 3115-3130. doi: 10.5194/acp-12-3115-2012

Song, W., Hess, K., Damby, D. E., Wadsworth, F. B., Lavallée, Y., Cimarelli, C., et al. (2014). Fusion characteristics of volcanic ash relevant to aviation hazards. Geophys. Res. Lett. 41, 2326-2333. doi: 10.1002/2013GL059182

Sparks, R. S. J., Bursik, M. I., Carey, S. N., Gilbert, J. S., Glaze, L. S., Sigurdsson, H., et al. (1997). Observations and Interpretation of Volcanic Plumes, in Volcanic Plumes. Chichester: John Wiley, 117-140.

Stevenson, J. A., Loughlin, S., Rae, C., Thordarson, T., Milodowski, A. E., Gilbert, J. S., et al. (2012). Distal deposition of tephra from the Eyjafjallajokull 2010 summit eruption. J. Geophys. Res. Solid Earth 117:B00C10. doi: 10.1029/ 2011JB008904

Tesche, M., Ansmann, A., Müller, D., Althausen, D., Engelmann, R., Freudenthaler, V., et al. (2009). Separation of dust and smoke profiles over cape verde by using multiwavelength Raman and polarization lidars during SAMUM 2008. J. Geophys. Res. 114:D13202. doi: 10.1029/2009JD011862

Trickl, T., Giehl, H., Jäger, H., and Vogelmann, H. (2013). $35 \mathrm{yr}$ of stratospheric aerosol measurements at Garmisch-Partenkirchen: from Fuego to Eyjafjallajökull, and beyond, Atmos. Chem. Phys. 13, 5205-5225. doi: 10.5194/ acp-13-5205-2013

Wang, X., Boselli, A., D’Avino, L., Pisani, G., Spinelli, N., Amodeo, A., et al. (2008). Volcanic dust characterization by EARLINET during Etna's eruptions in 2001-2002. Atm. Environ. 42, 893-905. doi: 10.1016/j.atmosenv.2007. 10.020

Wang, X., Boselli, A., Sannino, A., Song, C., Spinelli, N., Yiming Zhao, Y., et al. (2015). Calibration of multi-wavelength raman polarization lidar. EPJ Web Conf. 89:01002. doi: 10.1051/epjconf/20158901002

Weinzierl, B., Sauer, D., Minikina, A., Reitebuch, O., Dahlkötter, F., Mayer, B., et al. (2012). On the visibility of airborne volcanic ash and mineral dust from the pilot's perspective in flight. Phys. Chem. Earth Parts A/B/C 45-46, 87-102. doi: 10.1016/j.pce.2012.04.003 
Witt, V., Ayris, P. M., Damby, D. E., Cimarelli, C., Kueppers, U., and Dingwell, D. B. (2017). Volcanic ash supports a diverse bacterial community in a marine mesocosm. Geobiology 15, 453-463. doi: 10.1111/gbi.12231

Conflict of Interest Statement: The authors declare that the research was conducted in the absence of any commercial or financial relationships that could be construed as a potential conflict of interest.
Copyright $\odot 2018$ Boselli, Scollo, Leto, Sanchez, Sannino, Wang, Coltelli and Spinelli. This is an open-access article distributed under the terms of the Creative Commons Attribution License (CC BY). The use, distribution or reproduction in other forums is permitted, provided the original author(s) and the copyright owner(s) are credited and that the original publication in this journal is cited, in accordance with accepted academic practice. No use, distribution or reproduction is permitted which does not comply with these terms. 